University of Nebraska - Lincoln

DigitalCommons@University of Nebraska - Lincoln

\title{
Long-term impacts of invasive species on a native top predator in a large lake system
}

\author{
Scott A. Rush \\ University of Windsor, srush@cfr.msstate.edu \\ Gordon Paterson \\ University of Windsor \\ Tim B. Johnson \\ Glenora Fisheries Station \\ Ken G. Drouillard \\ University of Windsor \\ Gordon D. Haffner \\ University of Windsor \\ See next page for additional authors
}

Follow this and additional works at: https://digitalcommons.unl.edu/usgsstaffpub

Rush, Scott A.; Paterson, Gordon; Johnson, Tim B.; Drouillard, Ken G.; Haffner, Gordon D.; Hebert, Craig E.; Arts, Michael T.; Mcgoldric, Daryl J.; Backus, Sean M.; Lantry, Brian F.; Lantry, Jana R.; Schaner, Ted; and Fisk, Aaron T., "Long-term impacts of invasive species on a native top predator in a large lake system" (2012). USGS Staff -- Published Research. 563.

https://digitalcommons.unl.edu/usgsstaffpub/563

This Article is brought to you for free and open access by the US Geological Survey at DigitalCommons@University of Nebraska - Lincoln. It has been accepted for inclusion in USGS Staff -- Published Research by an authorized administrator of DigitalCommons@University of Nebraska - Lincoln. 


\section{Authors}

Scott A. Rush, Gordon Paterson, Tim B. Johnson, Ken G. Drouillard, Gordon D. Haffner, Craig E. Hebert, Michael T. Arts, Daryl J. Mcgoldric, Sean M. Backus, Brian F. Lantry, Jana R. Lantry, Ted Schaner, and Aaron T. Fisk 


\title{
Long-term impacts of invasive species on a native top predator in a large lake system
}

\author{
SCOTT A. RUSH*, GORDON PATERSON*, TIM B. JOHNSON ${ }^{\dagger}$, KEN G. DROUILLARD*, GORDON D. \\ HAFFNER*, CRAIG E. HEBERT ${ }^{\ddagger}$, MICHAEL T. ARTS ${ }^{\S}$, DARYL J. MCGOLDRICK ${ }^{\S}$ SEAN M. \\ BACKUS ${ }^{\S}$, BRIAN F. LANTRY ${ }^{\star}$, JANA R. LANTRY**, TED SCHANER ${ }^{\dagger}$ AND AARON T. FISK* \\ ${ }^{*}$ Great Lakes Institute for Environmental Research, University of Windsor, Windsor, ON, Canada \\ ${ }^{+}$Ontario Ministry of Natural Resources, Glenora Fisheries Station, Picton, ON, Canada \\ ${ }^{\ddagger}$ Environment Canada, National Wildlife Research Centre, Carleton University, Ottawa, ON, Canada \\ ${ }^{\S}$ Environment Canada, Water Science and Technology Directorate, Burlington, ON, Canada \\ 'U.S. Geological Survey, Great Lakes Science Center, Lake Ontario Biological Station, Oswego, NY, U.S.A. \\ **New York State Department of Environmental Conservation, Cape Vincent Fisheries Research Station, Cape Vincent, NY, U.S.A.
}

\section{SUMMARY}

1. Declining abundances of forage fish and the introduction and establishment of non-indigenous species have the potential to substantially alter resource and habitat exploitation by top predators in large lakes.

2. We measured stable isotopes of carbon $\left(\delta^{13} \mathrm{C}\right)$ and nitrogen $\left(\delta^{15} \mathrm{~N}\right)$ in field-collected and archived samples of Lake Ontario lake trout (Salvelinus namaycush) and five species of prey fish and compared current trophic relationships of this top predator with historical samples.

3. Relationships between $\delta^{15} \mathrm{~N}$ and lake trout age were temporally consistent throughout Lake Ontario and confirmed the role of lake trout as a top predator in this food web. However, $\delta^{13} \mathrm{C}$ values for age classes of lake trout collected in 2008 ranged from 1.0 to 3.9\%o higher than those reported for the population sampled in 1992.

4. Isotope mixing models predicted that these changes in resource assimilation were owing to the replacement of rainbow smelt (Osmerus mordax) by round goby (Neogobius melanostomus) in lake trout diet and increased reliance on carbon resources derived from nearshore production. This contrasts with the historical situation in Lake Ontario where $\delta^{13} \mathrm{C}$ values of the lake trout population were dominated by a reliance on offshore carbon production.

5. These results indicate a reduced capacity of the Lake Ontario offshore food web to support the energetic requirements of lake trout and that this top predator has become increasingly reliant on prey resources that are derived from nearshore carbon pathways.

Keywords: nearshore, Neogobius melanostomus, offshore, Salvelinus namaycush, stable isotopes

\section{Introduction}

The lake trout (Salvelinus namaycush, L.) is one of the most common native top predators in oligotrophic north temperate lakes and is an effective indicator of ecosystem health (Ryder \& Kerr, 1990; Scott \& Crossman, 1973; Kiriluk et al., 1995). In the Laurentian Great Lakes, factors including predation by sea lamprey (Petromyzon marinus, L.) and overfishing have contributed to the extirpation of lake trout, with the exception of Lake Superior (Bronte et al., 2003; Mills et al., 2003; Dobiesz et al., 2005). Rehabilitation efforts began in the Great Lakes in the late 1960s with stocking programs to sustain lake trout populations continuing to the present day in Lakes Erie, Huron, Ontario and Michigan. Since these programmes began, the primary prey base for lake trout has consisted of nonindigenous pelagic forage fish including alewife (Alosa pseudoharengus, Wilson) and rainbow smelt (Osmerus

Correspondence: Scott A. Rush, Department of Wildlife, Fisheries \& Aquaculture, Box 9690, Mississippi State University, Mississippi State, MS 39762, U.S.A. E-mail: srush@cfr.msstate.edu

Reproduced with the permission of the Minister of Environment. 
mordax, Mitchill). Over the past three decades, however, factors including top-down predation pressure, nutrient remediation programmes and invasive species introductions have reduced pelagic prey fish abundances throughout the Great Lakes (Bronte et al., 2003; Mills et al., 2003; Dobiesz et al., 2005). Further, the establishment of additional invasive species, including dreissenid mussels (Dreissena spp.) and round goby (Neogobius melanostomus, Pallus), has the potential to alter nutrient availability and production pathways in Great Lakes food webs (Johannsson et al., 2000; Hecky et al., 2004). For other predators, such as the herring gull (Larus argentatus, Pontoppidan), declining food abundance in the Great Lakes has resulted in substantially altered foraging activities, including increased proportions of terrestrial food items in their diet (Hebert et al., 2008). Less is known of the response of lake trout to such changes in the composition of the prey community. Lake Ontario lake trout now incorporate round goby in their diet (Dietrich, Morrison \& Hoyle, 2006) but the extent to which this novel prey item has changed lake trout foraging ecology and ecosystem structure is uncertain.

For predatory salmonids such as lake trout, the implications of changes to the prey base, prey spatial distributions and/or energy densities include higher specific foraging costs and a decreased ability to maintain adequate food consumption rates relative to daily bioenergetic budgets (Rand et al., 1994; Pazzia et al., 2002). Pazzia et al. (2002) tested the hypothesis that planktivorous lake trout expend more energy searching for and capturing small-bodied invertebrate prey than do piscivorous lake trout and thus must perform more work to acquire their daily ration. Temporal declines in size at age and energy densities have been documented for Lake Ontario lake trout concomitant with declining prey abundances and the introduction and establishment of round goby (Paterson et al., 2009). However, delineating the specific mechanisms responsible for such temporal changes in lake trout ontogeny requires the capacity to quantify a timeintegrated response of this top predator to ecosystem change.

Unlike stomach content analysis, biochemical tracers assimilated from the diet, such as the stable isotopes of carbon $\left(\delta^{13} \mathrm{C}\right)$ and nitrogen $\left(\delta^{15} \mathrm{~N}\right)$, can provide an integrative evaluation of diet of a top predator over extended time periods (Hebert, Arts \& Weseloh, 2006; Hebert et al., 2008). As dietary tracers, $\delta^{13} \mathrm{C}$ and $\delta^{15} \mathrm{~N}$ provide valuable information regarding the resource pathways exploited by individuals and their trophic position within the food web. Combined, these dietary tracers are increasingly used to understand changes in food-web structure (VanderZanden,
Casselman \& Rasmussen, 1999a; Vander Zanden et al., 1999b; Hebert et al., 2006). Further, in freshwater lakes, $\delta^{13} \mathrm{C}$ values are negatively correlated with depth, with nearshore benthic carbon production and consumers being characterised by elevated $\delta^{13} \mathrm{C}$ values relative to more negative values associated with offshore production and biota (Vander Zanden \& Rasmussen, 1999; Rennie, Sprules \& Johnson, 2009). Ecologically, consumer $\delta^{13} \mathrm{C}$ values therefore represent the production pathways (photosynthetic and detrital) and habitats exploited by an individual in addition to representing the assimilated fraction of the diet.

In this study, multiple age classes of lake trout and representative prey items were collected from Lake Ontario to investigate the stable isotope ecology of this top predator in a food web that has experienced substantial recent ecological change. Through a comparison with historical data and the use of archived specimens and present day collections, this research provides a novel evaluation of the long-term temporal changes in resource and habitat exploitation by lake trout in Lake Ontario that have occurred as the invasion of round goby. We predicted that our study would demonstrate the increasing importance of nearshore benthic resources to lake trout as a result of ecosystem-wide changes that have occurred in parallel with Ponto-Caspian species invasions (Vanderploeg et al., 2002).

\section{Methods}

\section{Sample collection}

Four hundred and nineteen lake trout were collected from 18 sites throughout Lake Ontario in September 2008 using bottom-set graded mesh gill nets (ranging in mesh size from 38 to $151 \mathrm{~mm}$, at $12.7 \mathrm{~mm}$ increments; Lantry \& Lantry, 2010). At each sampling location, three or four nets were set parallel to depth contours beginning at the $10{ }^{\circ} \mathrm{C}$ isotherm, rarely shallower than $25 \mathrm{~m}$, and proceeding in $10 \mathrm{~m}$ depth increments to a maximum of $50 \mathrm{~m}$ (M. Keir, pers. comm.). Forage fish and invertebrate prey items were collected from offshore sites by bottom trawl in Lake Ontario near Niagara on the Lake, Oswego, Port Credit and from within the eastern basin during summer/autumn 2007 and 2008. Prey species included alewife, rainbow smelt, slimy sculpin (Cottus cognatus, Richardson), mysid shrimp (Mysis diluviana, Lovén) and round goby. Immediately after collection, total length $(\mathrm{mm})$, weight $(\mathrm{g})$, sex and presence of fin clips and/or coded wire tags (indicating wild versus stocked origin) were recorded for each lake trout. A skinless, boneless dorsal muscle sample taken from the anterior portion of 
the dorsal fin on the left side of the fish was removed from each lake trout and muscle samples and whole prey items were immediately placed on dry ice before storing at $-80{ }^{\circ} \mathrm{C}$.

\section{Archived samples}

Lake trout and prey fish species have been collected from Lake Ontario since 1977 as sentinels of environmental remediation and food-web biomagnification (Kiriluk et al., 1997; McGoldrick et al., 2010). Following collection of biological data and subsequent whole body homogenization of specimens for pollutant analysis, subsamples of the homogenates were archived and stored in a $-80{ }^{\circ} \mathrm{C}$ specimen repository (National Aquatic Biological Specimen Bank - NABSB; McGoldrick et al., 2010). For the current study, c. $5 \mathrm{~g}$ aliquots of lake trout, alewife, rainbow smelt, slimy sculpin and round goby collected from throughout Lake Ontario from 1995 to 2003 were provided by NABSB archives (Table 1). Net plankton samples collected from Lake Ontario in 1995 were also provided by the NABSB. For all lake trout, fish were aged using

Table 1 Summary biological and isotope data for Lake Ontario lake trout and prey items collected from 1995 to 2008

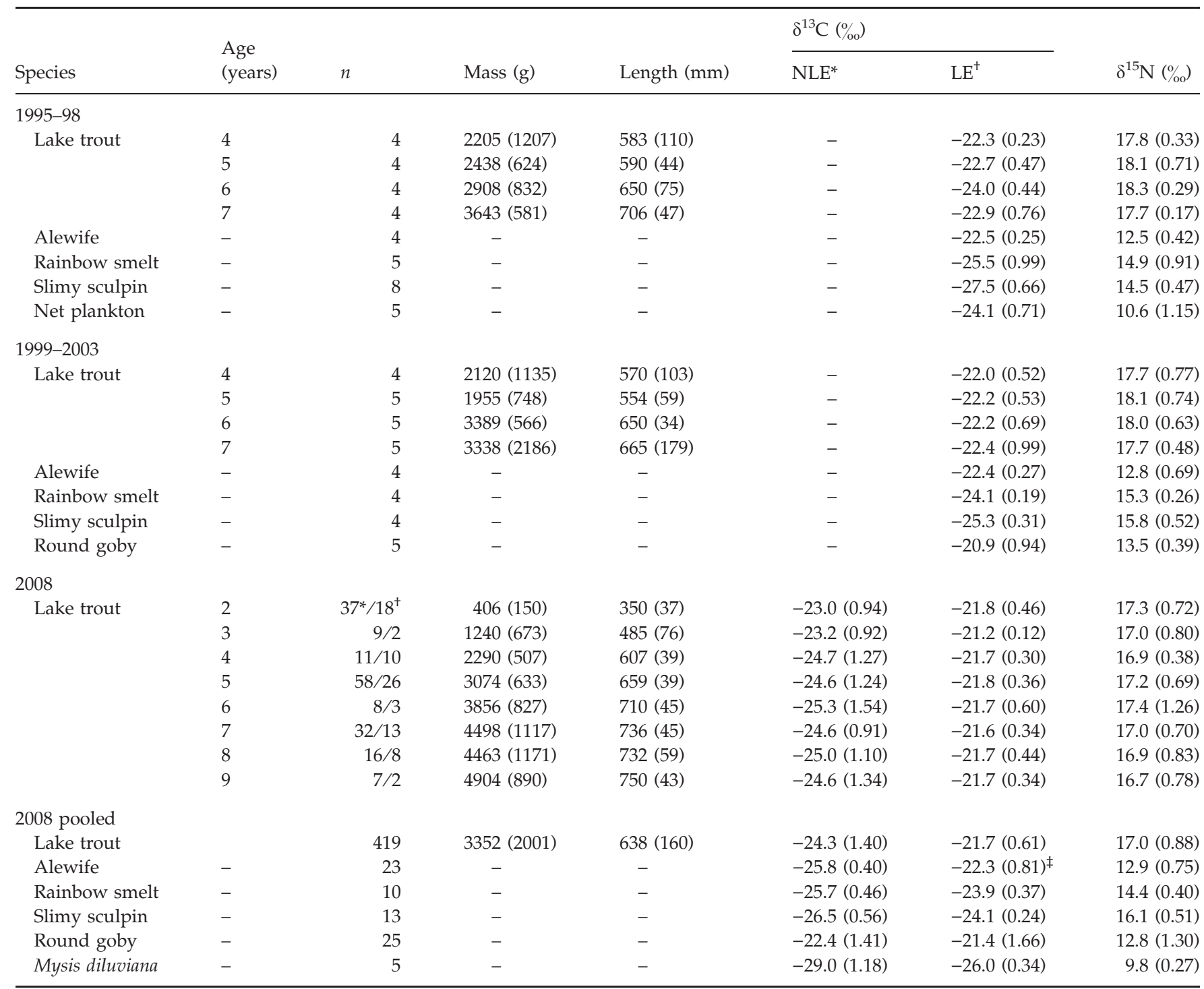

Values indicate mean with standard error in parentheses.

*Non-lipid-extracted (NLE) samples.

${ }^{\dagger}$ Lipid-extracted (LE) - sample size ( $n$ ) for LE reflects 216 fish including those of known age.

${ }^{\ddagger}$ Prey species $\delta^{13} \mathrm{C}$ isotope values corrected using sample carbon/nitrogen ratios as outlined by Post et al. (2007). 
combinations of fin clip and/or coded wire tag information in addition to calcified structures and existing age length relationships. Archived lake trout ranged from 4 to 7 years of age and lake trout and prey fish samples were separated into 1995-98 and 1999-2003 groups to reflect pre- and postround goby introduction periods, with the 2008 sample collection representing the current state of Lake Ontario with round goby now well established in the food web. With the exceptions of two lake trout specimens collected during July 1996, all archived samples represent fish initially netted from Lake Ontario from late August to early October during the respective collection years, including lake trout collected by Kiriluk et al. (1995).

\section{Historical data acquisition}

Historical stable isotope data for Lake Ontario lake trout and prey species (alewife, rainbow smelt, slimy sculpin and net plankton) were acquired from figures 7 and 10, respectively, of Kiriluk et al. (1995), using the GetData Graph Digitizer version 2.24 software package (Fedorov, 2008). Accuracy of data acquisition was determined using analyses of covariance to compare the regression models reported by Kiriluk et al. (1995) between lake trout age and $\delta^{13} \mathrm{C}$ or $\delta^{15} \mathrm{~N}$ with those relationships determined from the acquired data. Data acquisition was repeated until the relationships between the stable isotope values and lake trout age generated regression coefficients and intercepts within $95 \%$ of the respective values reported by Kiriluk et al. (1995). For prey fish, data acquisition was repeated until the average prey stable isotope values and standard errors for the acquired data were within $5 \%$ of the original values reported in Table 1 of Kiriluk et al. (1995).

\section{Stable isotope analysis}

Stable isotope analyses were completed on the 2008 lake trout samples using lipid-extracted (LE) and/or nonlipid-extracted (NLE) sample preparations. NLE samples were completed to facilitate comparison with the historical data generated for Lake Ontario lake trout by Kiriluk et al. (1995). For Lake Ontario lake trout samples collected between 1995 and 2003 and provided from the specimen archive, stable isotope analyses were completed on LE samples only. Prey samples collected in 2008 did not undergo lipid extraction but were normalised using sample carbon/nitrogen ratios as outlined by Post et al. (2007). Stable isotope analyses were completed on whole body homogenates for all prey fish samples.

Prior to stable isotope analysis, lake trout muscle tissues and prey items were freeze-dried for $48 \mathrm{~h}$ and subsamples of lake trout and prey items were cryogenically homogenised using a mortar and pestle and liquid nitrogen. Lipids were extracted using a $2: 1$ chloroform/methanol solution (Folch, Lees \& Sloane Stanley, 1957). Stable isotope analyses were completed using a Delta Plus isotope-ratio mass spectrometer (ThermoFinnigan, San Jose, CA, U.S.A.) coupled with an elemental analyser (Costech, Valencia, CA, U.S.A.). Values of $\delta^{13} \mathrm{C}$ and $\delta^{15} \mathrm{~N}$ were quantified in relation to three internal laboratory standards and an NIST standard (\#8414 bovine muscle) which was run every 12 samples. Atmospheric nitrogen and Vienna Pee Dee Belemnite carbonate were the standard reference materials for ${ }^{15} \mathrm{~N}$ and ${ }^{13} \mathrm{C}$, respectively. The analytical precision based on the standard deviation of NIST standard 8414 (72 standards analysed) for $\delta^{15} \mathrm{~N}$ was $0.19 \%$ and for $\delta^{13} \mathrm{C}$ was $0.04 \%$. The analysis of other NIST standards (sucrose NIST 8542 and ammonium sulphate NIST 8547, $n=3$ for each) generated values that were within 0.01 and $0.07 \%$ of certified values for $\delta^{15} \mathrm{~N}$ and $\delta^{13} \mathrm{C}$, respectively. All stable isotope analyses were completed by the Trophic Ecology Laboratory at the University of Windsor's Great Lakes Institute for Environmental Research.

Stable isotope analyses were completed on a total of 419 Lake Ontario lake trout collected in 2008 ranging from 2 to 9 years of age (Table 1). NLE $\delta^{13} \mathrm{C}$ stable isotope values were generated for all of these samples with LE $\delta^{13} \mathrm{C}$ stable isotope analysis completed on a subset of 216 individuals. Although tissue analysed from lake trout collected in 2008 are dorsal muscle and thus differ from the whole body homogenates of fish collected prior to 2008, analysis of $\delta^{13} \mathrm{C}$ values from LE samples showed no statistical pattern (Table S1). Thus, the similarity in $\delta^{13} \mathrm{C}$ values between tissue sample types supports Post et al. (2007) in suggesting that muscle tissues tend to dominate whole body homogenates and can provide representative isotope information for aquatic species, provided that the potential influence of lipids is considered.

A total of 35 archived lake trout subsamples, 34 prey fish composite subsamples, and five net plankton samples collected from Lake Ontario between 1995 and 2003, were provided from the NABSB (McGoldrick et al., 2010), (Table 1). For all archived specimens, $\delta^{13} \mathrm{C}$ stable isotope analyses were completed using LE tissues only. A minimum of 10 individuals of each prey fish species were analysed for stable isotopes in addition to five pooled samples of M. diluviana.

\section{Statistics and isotope modelling}

Prior to statistical analysis, the normality of all data was assessed using visual inspections of normal probability 
plots and with Shapiro-Wilk tests. Analyses of variance (ANOVAs) were corrected for the covariates of lake trout total length or age where necessary. Relationships between $\delta^{13} \mathrm{C}$ and $\delta^{15} \mathrm{~N}$ values and fish age were evaluated using analysis of covariance (ANCOVA). All statistical models were generated using the $R$ statistical package ( $R$ Development Core Team, 2010) with the criterion of significance for all statistical tests being $P<0.05$.

The proportional contribution of each prey item to the diet of lake trout collected in 2008 was evaluated using mixing models run in the program MixSIR, a computational program that can provide estimates of the relative contributions of diet sources to an organism (Moore \& Semmens, 2008). All mixing models have underlying assumptions such as which food resources to include and which trophic fractionation factors to apply. The decision to include particular prey items in the mixing models was based on literature searches focussed on identifying the most important lake trout diet items pre- and post-round goby introduction (Brandt, 1985; Borgmann \& Whittle, 1992; Rand \& Stewart, 1998; Dietrich et al., 2006). These studies indicate that the combinations of alewife, rainbow smelt, slimy sculpin and round goby represent more than $90 \%$ of the prey items consistently observed in Lake Ontario lake trout stomachs by both number and mass pre- and postround goby introduction. Additional species in the Lake Ontario prey fish community, including yellow perch (Perca flavescens, Mitchill), gizzard shad (Dorosoma cepedianum, Rafinesque), logperch (Percina caprodes, Rafinesque), shiners (Notropis spp.) and stickleback (Gaserosteus aculeatus, L.) have been demonstrated to contribute negligibly to lake trout diet over an annual period (Brandt, 1985; Dietrich et al., 2006). For all MixSIR simulations, LE lake trout and mathematically lipid-normalised prey fish isotope values (Post et al., 2007) were used in combination with the isotopic fractionation factors for lake trout reported by Vander Zanden \& Rasmussen $(2001)\left(\delta^{13} \mathrm{C}: 0.05 \pm 0.23 \%\right.$; and $\delta^{15} \mathrm{~N}: 3.49 \pm 1.08 \%{ }_{0}$ ).

MixSIR uses a Bayesian framework, designed to estimate the probability distributions of source contributions to a mixture, while explicitly accounting for uncertainty with multiple sources, fractionation and isotope values. Using uninformative priors and estimates of uncertainty associated with mixing model inputs, each MixSIR model ran for $1 \times 10^{7}$ iterations, resulting in convergence on the posterior source contributions of the different prey items contributing to lake trout diet. The maximum importance ratio was below 0.001 , suggesting that our models were effective in estimating the true posterior density (Moore \& Semmens, 2008). Results of the MixSIR models are presented as medians and the 5th and 95th credibility intervals.
The two-source isotope mixing model developed by Vander Zanden \& Vadenboncoeur (2002) was used to estimate the extent of lake trout reliance on nearshore and/or offshore carbon resources for the historical data presented by Kiriluk et al. (1995) and the timeframe of samples included in this study (eqn 1).

$$
\left(\delta^{13} \mathrm{C}_{\mathrm{c}}-\delta^{13} \mathrm{C}_{\mathrm{p}}\right) /\left(\delta^{13} \mathrm{C}_{1}-\delta^{13} \mathrm{C}_{\mathrm{p}}\right)
$$

Where $\delta^{13} \mathrm{C}_{\mathrm{c}}$ is the consumer (lake trout) isotope value, $\delta^{13} \mathrm{C}_{\mathrm{p}}$ is the pelagic (offshore) prey average value and $\delta^{13} \mathrm{C}_{1}$ is the littoral (nearshore) prey value. For the 1992 data of Kiriluk et al. (1995), we estimated $\delta^{13} \mathrm{C}$ endpoints (baselines) for offshore and inshore habitats for use in the two-source mixing model using the isotope data provided by Kiriluk et al. (1995) and assuming trends consistent with those demonstrated for $\delta^{13} \mathrm{C}$ values in primary consumers collected from nearshore, offshore and deep profundal habitats (France, 1995; Hecky \& Hesslein, 1995; Vander Zanden \& Rasmussen, 1999). Herein, to estimate a nearshore $\delta^{13} \mathrm{C}$ baseline for the 1992 collections, we used an average $\delta^{13} \mathrm{C}$ of $-27.5 \%$ determined from the net plankton $\delta^{13} \mathrm{C}$ values reported by Kiriluk et al. (1995) and considered this value to represent the offshore primary consumer $\delta^{13} \mathrm{C}$ model end member. Assuming an average difference of $-4.6 \%$ between offshore and nearshore habitats (Vander Zanden \& Rasmussen, 1999), we generated an estimate of $-22.9 \%$ for the nearshore $\delta^{13} \mathrm{C}$ baseline for Lake Ontario in 1992. From this nearshore $\delta^{13} \mathrm{C}$ baseline, a mean nearshore prey $\left(\delta^{13} \mathrm{C}_{1}\right)$ value of $-22.1 \%$ o was calculated based on an average trophic fractionation value of $0.8 \%$ for $\delta^{13} \mathrm{C}$ determined for secondary consumer prey fish species (Vander Zanden \& Rasmussen, 2001).

For the 1995-98, 1999-2003 and 2008 collections, $\delta^{13} \mathrm{C}$ endpoints for offshore and nearshore habitats were also estimated using stable isotope data generated from the current collections and literature-based fractionation values available for the prey species. For the 1995-98 collection period, an offshore $\delta^{13} \mathrm{C}$ baseline of $-24.1 \%$ was determined from net plankton samples collected in 1995 and provided by the NABSB. For alewife collected between 1995 and 1998, an enrichment factor of 2.6\% was estimated for $\delta^{13} \mathrm{C}$ between this consumer and their zooplankton primary consumer prey. This enrichment factor was used to generate $\delta^{13} \mathrm{C}$ offshore baselines for the 1999-2003 and 2008 collection periods.

In Lake Ontario, round goby diets are dominated by primary consumers including dreissenid mussel, chironomid and amphipod species (Taraborelli et al., 2010). Using $\delta^{13} \mathrm{C}$ data for these prey species and round goby collected from Lake Erie by Campbell et al. (2009), a 
trophic fractionation value of $0.25 \%$ was estimated for $\delta^{13} \mathrm{C}$ between round goby and these prey items. This fractionation value was used to generate $\delta^{13} \mathrm{C}$ nearshore baselines of -21.1 and $-21.6 \%$ for the 1999-2004 and 2008 monitoring periods, respectively.

For both the Kiriluk et al. (1995) and current data, the $\delta^{13} \mathrm{C}_{\mathrm{p}}$ value in the two-source mixing model was the average $\delta^{13} \mathrm{C}$ signature for alewife, rainbow smelt and slimy sculpin from the respective sampling years. In the absence of prey fish species from nearshore locations for the $1995-98$ collections, a mean nearshore prey $\left(\delta^{13} C_{1}\right)$ value of $-20.7 \%$ was estimated using the average trophic fractionation value of $0.8 \%$ for $\delta^{13} \mathrm{C}$ reported for secondary consumer prey fish species (Vander Zanden \& Rasmussen, 2001). For the 1999-2003 and 2008 collection data, the average round goby $\delta^{13} \mathrm{C}$ was used as the nearshore signature $\left(\delta^{13} \mathrm{C}_{1}\right)$ in the model. The model was run on an individual consumer basis and under the condition of negligible trophic fractionation $(0.05 \%)$ of $\delta^{13} \mathrm{C}$ for lake trout (Vander Zanden \& Rasmussen, 2001) with end member contributions calculated as outlined by Vander Zanden \& Vadenboncoeur (2002). LE lake trout and prey $\delta^{13} \mathrm{C}$ values were used for the two-source mixing model simulations for the 1995-98, 1999-2003 and 2008 collection periods. A summary of the data used in the two-source mixing model are provided in Table S2.

\section{Results}

Lipid-extracted $\delta^{13} \mathrm{C}$ data

Fin clip and coded wire tag information indicated that all of the lake trout captured during the 2008 collections were stocked fish. Great Lakes lake trout are primarily represented by two morphotypes, specifically the siscowet and lean forms. Siscowet lake trout typically inhabit deep $(>100 \mathrm{~m})$ waters, are exceedingly high in lipids $(\geq 40 \%)$ and currently only exist in Lake Superior (Krueger \& Ihssen, 1995). Lean lake trout have much lower lipid content $(\leq 20 \%)$, typically inhabit depths up to $100 \mathrm{~m}$ but usually $<80 \mathrm{~m}$ and are the only morphotype stocked in the lower Great Lakes, including Lake Ontario (Elrod et al., 1995; Lantry \& Lantry, 2010). All lake trout analysed in the current and previous Lake Ontario isotopic studies were of the lean morphotype (Krueger \& Ihssen, 1995); the native population was extirpated in the 1950s and all fish stocked during 1971-2008 were leans (Elrod et al., 1995; Lantry \& Lantry, 2010). Lake Ontario lake trout $\delta^{13} \mathrm{C}$ values increased significantly relative to pre-goby introduction (1999) in Lake Ontario (Fig. 1). Specifically, temporal increases (enrichment) of $\mathrm{LE} \delta^{13} \mathrm{C}$ were deter- mined for 4-, 5-, 6- and 7-year-old lake trout collected from Lake Ontario from 1995 to 2008. The enrichment of $\delta^{13} \mathrm{C}$ was greatest for 6- and 7-year-old lake trout for which $\delta^{13} \mathrm{C}$ values were higher by 2.2 and $1.9 \%$, respectively, from 1995 to 2008.

Carbon stable isotope values for alewife, rainbow smelt and slimy sculpin demonstrated similar temporal increases with individuals collected in 2008 having the highest average $\delta^{13} \mathrm{C}$ values across the collection periods (Table 1). Round goby had the highest $\delta^{13} \mathrm{C}$ values of the prey fish species, averaging $-20.9 \pm 0.9 \%$ for fish collected between 1999 and 2003 and $-21.4 \pm 1.7 \%$ for the 2008 collected fish. Of the prey species collected, the $M$. diluviana samples from 2008 had the most negative $\delta^{13} \mathrm{C}$ values. For round goby and Mysis, these trends were consistent for both the LE and $\mathrm{C} / \mathrm{N}$ ratio-corrected prey $\delta^{13} \mathrm{C}$ results. Slimy sculpin had the highest $\delta^{15} \mathrm{~N}$ values of the prey species with the exception of the 1995-98 collection period when rainbow smelt had a marginally higher $\delta^{15} \mathrm{~N}$ value $(14.9 \pm 0.9 \%)$ relative to slimy sculpin $(14.5 \pm 0.5 \%$ o $)$. Nitrogen stable isotope values for alewife changed negligibly over the collection periods, ranging from an average of $12.8 \pm 0.7 \%$ for individuals collected in 1995-98 to a mean of $12.9 \pm$ $0.7 \%$ for the 2008 collection.

MixSIR stable isotope modelling estimated that alewife and round goby dominated the diet of 2008 lake trout constituting $78 \%$ or more of the total prey items for the sizes of lake trout collected in this study (Table 2). Alewife were estimated to contribute an average of $50.2 \%(95 \%$ credible interval $42.9-57.1 \%$ ) of the lake trout diet with round goby estimated to constitute $41.5 \%$ (95\% credible interval $37-46 \%$ ) of the diet for lake trout, ranging in size from 290 to $849 \mathrm{~mm}$ (Table 2). Rainbow smelt and slimy sculpin were each estimated to constitute $<10 \%$ of the 2008 lake trout diet with Mysis estimated to provide a limited contribution $(\leq 2 \%)$ to the diet of the size range of lake trout collected for this study.

For 4-7-year-old lake trout collected from 1995 to 1998, $\delta^{13} \mathrm{C}$ values ranged from -21.9 to $-24.5 \%$ and averaged $-23.0 \pm 0.2 \%$ (mean $\pm \mathrm{SE}$ ). Nitrogen stable isotope values averaged $18.0 \%$ for fish from this early collection period. Carbon stable isotope values for the same ages of archived specimens collected from 1999 to 2003 ranged from -21.2 to $-23.9 \%$ and averaged $-22.2 \pm 0.2 \%$. For these fish, $\delta^{15} \mathrm{~N}$ averaged $17.9 \pm 0.1 \%$. For lake trout collected in $2008, \delta^{13} \mathrm{C}$ values for 2-9-year-old fish ranged from -21.1 to $-22.5 \%$. Average $\delta^{13} \mathrm{C}(-21.7 \%)$ and $\delta^{15} \mathrm{~N}(16.7 \%)$ were determined to be the same for lake trout collected in 2008 and ranging from 2 to 9-year-olds and 4 to 7-year-olds. Analyses of variance (ANOVA) demonstrated significant differences in average $\delta^{13} \mathrm{C}$ between the time periods 
A

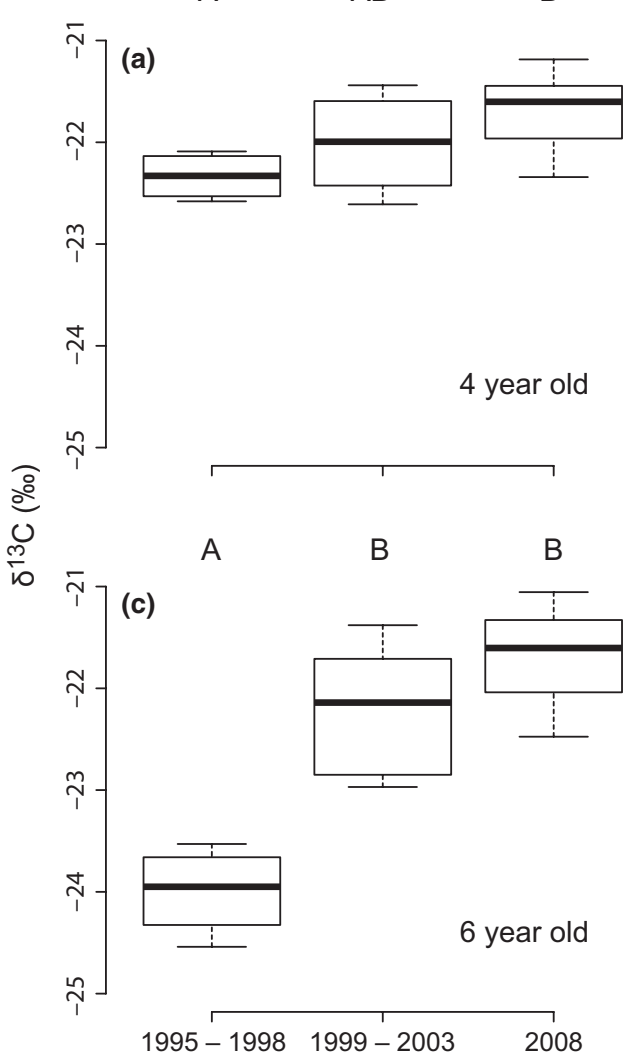

A

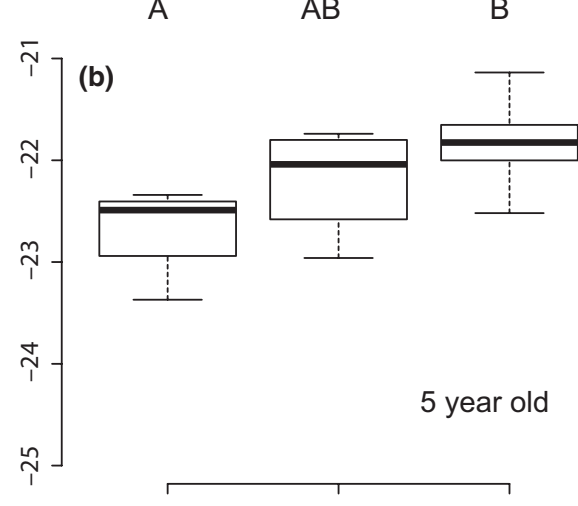

A

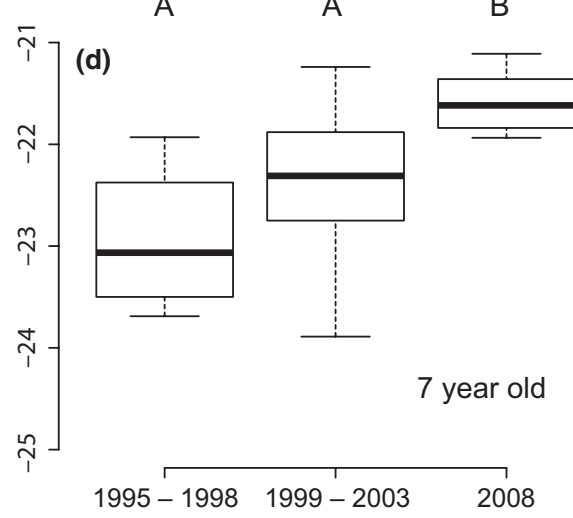

Fig. 1 Boxplots indicating isotopic comparisons for (a) 4-, (b) 5-, (c) 6- and (d) 7-year-old lake trout collected from Lake Ontario between 1995 and 2008. The boxed area represents the mean \pm quartile and the whiskers extend out to the minimum and maximum values. Unique letters reflect significant differences evaluated using Tukey Honest Significant Differences.

Table 2 Stable isotope mixing model (MixSIR) diet predictions for 2008 collected Lake Ontario lake trout length classes. Estimates represent per cent diet contribution obtained using MixSIR

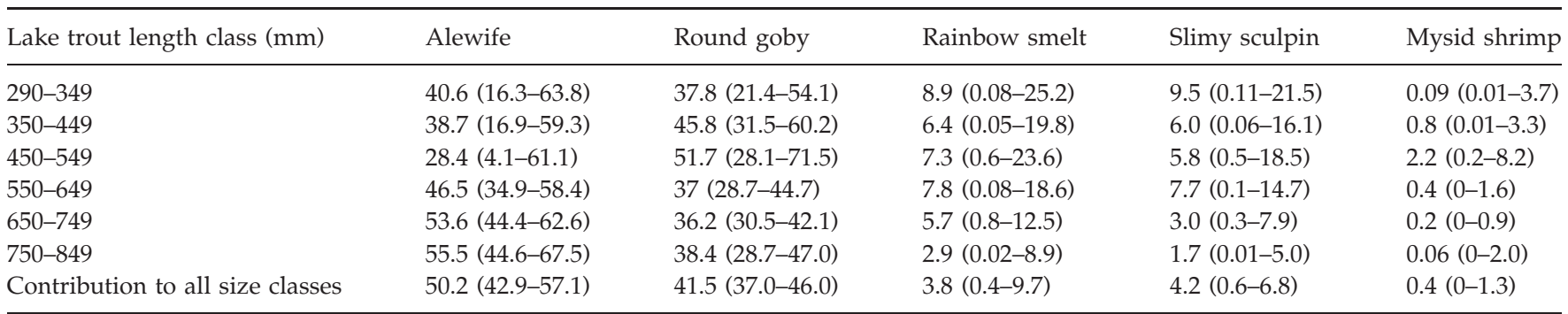

Median values are presented with the 5th and 95th per cent credibility intervals included in the parentheses.

1995-98 and 2008 for all age classes (Tukey HSD all $P<0.05$ ), with higher values in the 2008 period (Fig. 1).

\section{Non-lipid-extracted $\delta^{13} \mathrm{C}$ data}

In contrast to the positive relationship demonstrated by Kiriluk et al. (1995) between $\delta^{13} \mathrm{C}$ and Lake Ontario lake trout aged 3-9 years (Fig. 2), a negative relationship was observed between these variables for the 2008 NLE lake trout samples from the current study (ANCOVA; $\left.F_{1,180}=23.170 ; P<0.001\right)$. NLE $\delta^{13} \mathrm{C}$ results for the 2008 collected lake trout averaged $-24.6 \pm 0.1 \%$ for 3-9-yearold fish in comparison with an average $\delta^{13} \mathrm{C}$ of $-26.3 \%$ reported by Kiriluk et al. (1995) for these age classes. Nitrogen stable isotope values for the 2008 lake trout were elevated relative to the $\delta^{15} \mathrm{~N}$ results reported by Kiriluk et al. (1995) averaging $17.1 \pm 0.1 \%$ in 2008 relative to $16.1 \%$ for the historical collection. No significant difference was found between the regressions describing the relationships between $\delta^{15} \mathrm{~N}$ and age for the 2008 and the Kiriluk et al. (1995) data (ANCOVA; $F_{1,193}=1.303$; $P=0.303)$. 

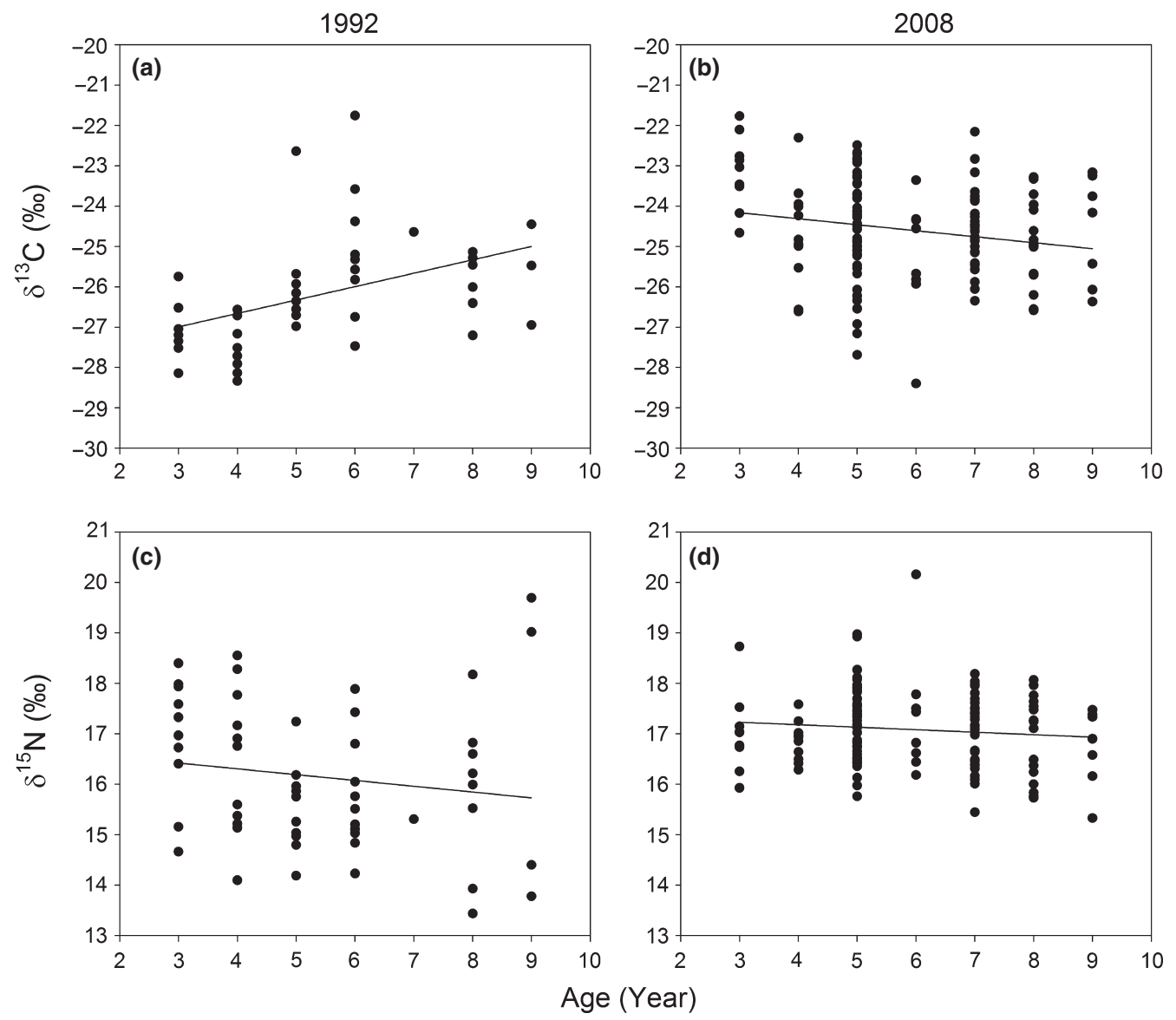

Fig. 2 Relationships between carbon and nitrogen isotopes and lake trout age. Lake Ontario lake trout age shown in years for samples collected in 1992 (panels a, c) and 2008 (panels b, d). Data presented in panels (a) and (c) are reproduced from Kiriluk et al. (1995).

The two-source isotope mixing model of Vander Zanden \& Vadenboncoeur (2002) estimated substantial temporal changes in lake trout carbon resource exploitation (Fig. 3). For the 1992 population sampled by Kiriluk et al. (1995), model estimates indicated that the $\delta^{13} \mathrm{C}$ values for these individuals averaged an $80 \%$ reliance on offshore production resources with only $10 \%$ of these individuals being classified as primarily reliant on nearshore production. For the 1995-98 and 1999-2003 collected lake trout, mean reliance on nearshore carbon increased from 41 to $56 \%$ in this time frame with $61 \%$ of lake trout collected in the latter time period being classified as primarily reliant on nearshore production. By 2008, model results indicated that lake trout $\delta^{13} \mathrm{C}$ values were representative of an $81 \%$ reliance on nearshore carbon resources with $93 \%$ of the individuals collected in this year having $\delta^{13} \mathrm{C}$ values that support primary dependence on nearshore production resources.

\section{Discussion}

The present study demonstrates that significant temporal change in Lake Ontario lake trout resource exploitation has occurred following the introduction and establishment of the round goby. This change occurred during a period when the abundances of alewife and rainbow smelt prey have also decreased in Lake Ontario (Connerton \& Schaner, 2007). Hebert et al. (2008) demonstrated a similar long-term temporal enrichment of $\delta^{13} \mathrm{C}$ values in Great Lakes herring gull colonies that was attributed to a diet shift to inclusion of terrestrial food as a consequence of reduced pelagic forage fish abundances throughout the basin. Lipid contents and average size of Great Lakes lake trout populations, including Lake Ontario, have demonstrated temporal declines concomitant with such decreases in prey fish abundances across the basin (Paterson et al., 2009). The current results indicate a similar response of a Great lakes lake trout population in that their foraging activities have changed substantially under conditions of altered prey species availability. From this perspective, this study reinforces the significance of mechanisms such as benthic pelagic coupling, whereby resource subsidies from non-traditional habitats provide important contributions to food-web trophic interactions and energy flow (Vander Zanden et al., 1999a; Higgins \& Vander Zanden, 2010). 

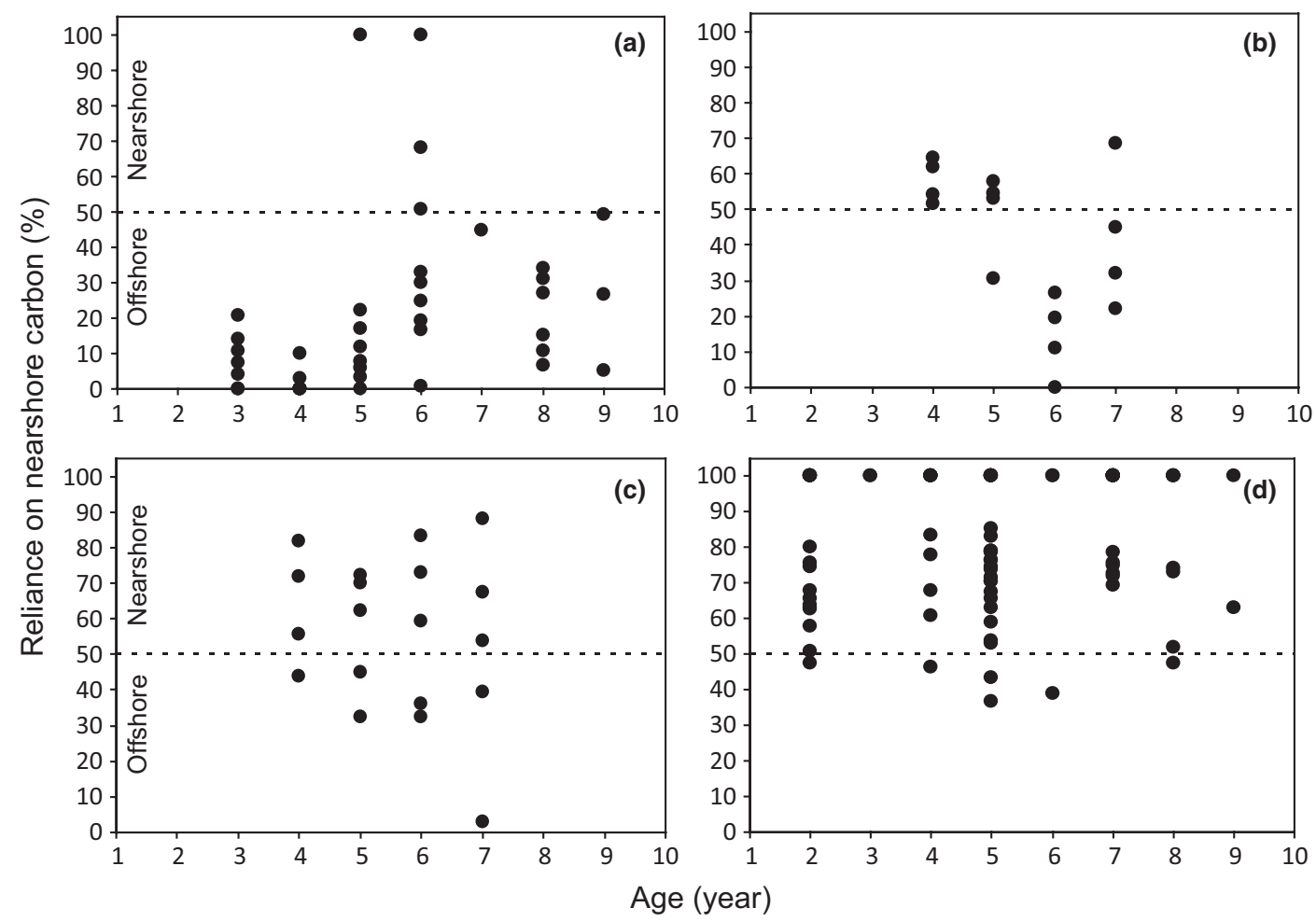

Fig. 3 Nearshore and offshore contributions to the diet of lake trout collected in (a) 1992, (b) 1994-98, (c) 1999-2003 and (d) 2008. Predicted contributions reflect nearshore (values above dashed line) and offshore (values below dashed line) carbon resources for Lake Ontario. Values in panel (a) reflect non-lipid-extracted lake trout samples (Kiriluk et al., 1995), while those in panels (b-d) denote lipid-extracted samples.

For the older ages of lake trout (6-9 years) included in the current study, growth rates declined by c. $2-10 \%$ per year. For such slow growing individuals, metabolic turnover rather than dietary assimilation and growth is expected to dominate long-term changes in isotope values (Hesslein, Hallard \& Ramlal, 1993). Specifically, $\delta^{13} \mathrm{C}$ metabolic turnover rates in a cold-water slowly growing species are estimated at $0.18 \%$ per day for 3-4-year-old fish (Hesslein et al., 1993), equating to a time of 4.6 years for $95 \%$ turnover of an individual's $\delta^{13} \mathrm{C}$ value. Under these considerations, lake trout $\delta^{13} \mathrm{C}$ values represent a long-term resource assimilation signal, especially for older individuals that are approaching zero growth. In contrast, for younger, more rapidly growing fish, changes in isotopic composition are dominated by the rapid assimilation of the dietary isotope values (Hesslein et al., 1993). The 2-year-old lake trout collected in 2008 for the current study averaged $380 \mathrm{~g}$ at the time of collection. This cohort was stocked into the lake in 2007 at an average mass of $48.7 \mathrm{~g}$ (http://www.glfc.org/fishstocking/) demonstrating that these individuals experienced full somatic tissue replacement during their first full year of growth in the lake. Such rapid growth kinetics dictates that any residual isotope signal from hatchery food would have been rapidly replaced by the wild diet following stocking into the lake (Hesslein et al., 1993).

Morbey et al. (2006) demonstrated that substantial variability can exist regarding nearshore and offshore habitat exploitation for a lake trout population. The two-source mixing model predictions from the current study suggest that the Lake Ontario lake trout population sampled in 2008 represents individuals that have primarily exploited nearshore-based production pathways throughout their lives. This contrasts with the 1992 Lake Ontario lake trout population sampled by Kiriluk et al. (1995), which was characterised by individuals mainly dependent on offshore carbon production during their lifespan. These results pose a novel problem for salmonid management programmes in Lake Ontario and throughout the Great Lakes, where declining forage fish abundances and invasive species represent potential limitations to programme success (Bronte et al., 2003; Mills et al., 2003; Dobiesz et al., 2005). Since 1997, Lake Ontario lake trout stocking efforts have relied heavily on fingerlings derived from Seneca Lake, New York, U.S.A., a population that is relatively resilient to mortality from lamprey predation (Schneider et al., 1996; Brenden et al., 2011). However, research indicates that recent increased mortality of stocked individuals in Lake 
Ontario may also be attributable to the ecosystem level changes in zooplankton and macroinvertebrate communities following the establishment of dreissenids in the lake (Brenden et al., 2011). Thus, although pelagic prey fish abundances are a contributing factor for establishing salmonid stocking quotas, these programmes will now also need to consider the increasing importance of round goby and benthic production pathways for the management of these recreational fisheries.

The introductions of dreissenid mussels (Dreissena bugensis, Andrusov and Dreissena polymorpha, Pallas) into the Great Lakes have been associated with a redirection of offshore production into the benthic zones of lakes where large colonies of these invasive species have become established (Johannsson et al., 2000; Hecky et al., 2004). The first records of appearance in Lake Ontario are 1989 (D. polymorpha) and 1991 (D. bugensis; Mills et al., 2003). The two-source mixing model predicted that lake trout collected between 1995 and 1998 were beginning to exhibit increased reliance on nearshore production relative to individuals collected by Kiriluk et al. (1995) in 1992. These predictions indicate that even prior to the introduction of the round goby in Lake Ontario changes were occurring to production pathways in this lake. The loss of populations of the deepwater amphipod Diporeia sp. in the Great Lakes has been attributed to the establishment of dreissenid mussels (Bronte et al., 2003; Mills et al., 2003; Dobiesz et al., 2005). In Lake Ontario, the decline of this important prey resource for forage species including rainbow smelt and slimy sculpin was reported to have been initiated in 1992. Rainbow smelt, slimy sculpin and alewife $\delta^{13} \mathrm{C}$ values were higher for specimens collected between 1995 and 1998 relative to those reported for these species by Kiriluk et al. (1995). Although Kiriluk et al. (1995) did not account for lipids in their $\delta^{13} \mathrm{C}$ analyses, such increases in $\delta^{13} \mathrm{C}$ values suggest a change in resource utilization by these Lake Ontario pelagic forage fish species. Such temporal trends of increasing $\delta^{13} \mathrm{C}$ values for Lake Ontario forage fish also provide evidence for the redirection of offshore resources in Great Lakes food webs that is associated with the establishment of dreissenids in these lakes (Johannsson et al., 2000; Hecky et al., 2004).

Such redirection of offshore production has also been hypothesised to have contributed to the reduced capacity of Great Lakes offshore habitats to support high densities of forage fish species (Hebert et al., 2008). Lake trout display remarkable diet plasticity (Scott \& Crossman, 1973) and will exploit more readily available prey during periods of reduced abundances of preferred prey (Martin, 1954, 1966). For example, planktivorous lake trout transplanted into a lake containing coregonid prey rapidly switched to piscivory following introduction into the new food web (Martin, 1966). For Great Lakes herring gulls, the diet shift to include terrestrial food resources resulted in a change in gull trophic position in addition to potential loss of reproductive fitness (Hebert, Shutt \& Ball, 2002; Hebert et al., 2008). If the nearshore $\delta^{13} \mathrm{C}$ production signal is being extended into the offshore waters of Lake Ontario, such as via round goby expansion into deeper offshore habitats (Walsh, Dittman \& O'Gorman, 2007), there may also be additional considerations for lake trout consuming round goby.

The MixSIR stable isotope modelling results from the current study predicted that round goby now represent a significant component of the diet for all sizes of Lake Ontario lake trout. These modelling results corroborate stomach content analysis (Dietrich et al., 2006), indicating that round goby have replaced rainbow smelt as the second most important prey item in the Lake Ontario lake trout diet. Energy densities measured for Lake Erie round goby were lower than those of rainbow smelt (Johnson, Bunnell \& Knight, 2005). Should this condition also be true for the energy densities of these species in Lake Ontario, this implies higher net foraging costs for lake trout in this system (Kerr, 1971a,b; Rand et al., 1994; Pazzia et al., 2002). The round goby is also a cryptobenthic, non-schooling species that lacks a swim bladder and inhabits cobble, sandy and vegetated substrates in Great Lakes habitats (Miller, 1986; Jude \& Deboe, 1996; Ray \& Corkum, 2001). This contrasts with the pelagic open water schooling behaviour of lake trout prey species such alewife and rainbow smelt. For lake trout $\delta^{13} \mathrm{C}$ values to have demonstrated the temporal increase observed in the current study is consistent with increased foraging success in the benthic habitats favoured by the round goby. Such benthic feeding activities have been predicted to decrease lake trout growth efficiencies owing to the generally smaller body sizes of benthic prey species (Pazzia et al., 2002). Lake trout populations that feed on smaller lower energy prey such as zooplankton also grow to smaller size and mature at a younger age (Martin, 1966). Energy densities and average size of Lake Ontario lake trout declined from 1995 to 2004 (Paterson et al., 2009) indicating a substantial change in the energy budget for this population during the time frame of the current study. However, round goby abundances increased in Lake Ontario since 2004 (Walsh et al., 2007) and the extent to which such changes in lake trout condition have continued following this time period is unknown. Whether these manifestations represent the primary ecological responses of lake trout to a shift in diet composition or significant adverse changes in lake trout growth and condition owing to lower quality prey or 
increased foraging costs is difficult to distinguish. However, for a species whose conservation target throughout the Great Lakes remains the establishment of self-sustaining populations, such long-term changes in lake trout resource exploitation, growth, and condition must be taken into consideration.

Dietrich et al. (2006) demonstrated the inclusion of round goby in the diets of lake trout collected from eastern Lake Ontario and indicated that this species was only contributing significantly to the diet of larger (450$649 \mathrm{~mm}$ ) lake trout. The isotope mixing model results of the current study predicted that round goby are now a significant prey item for all sizes of Lake Ontario lake trout. Fish from the study of Dietrich et al. (2006) were collected in 2004 and round goby abundance in the US waters of Lake Ontario increased significantly between 2002 and 2005 (Walsh et al., 2007). Additionally, the enrichment of $\delta^{13} \mathrm{C}$ values determined for 4-7-year-old lake trout collected from 1994 to 2008 underline increasing reliance on benthic production of this top predator in Lake Ontario. The 2008 field-collected samples used in the current study also include individuals netted from throughout Lake Ontario, indicating that round goby and their nearshore carbon signal now represent a widespread component of the lake trout diet in this lake. These results support the ecological engineering hypothesis whereby round goby have facilitated the redistribution of dreissenid bound carbon to piscivorous predators such as lake trout in invaded food webs (Vanderploeg et al., 2002). For lake trout, this diet shift, however, may also prove to aid their rehabilitation in Lake Ontario. Round goby are much lower in thiaminase content relative to the rainbow smelt they have replaced in the Lake Ontario lake trout diet (Tillitt et al., 2005). Salmonid diets rich in alewife and rainbow smelt prey lead to thiamine deficiency in lake trout, which has been associated with impeding the successful establishment of selfsustaining Great Lakes populations (Fitzsimons et al., 1999).

Although the inclusion of round goby in the diet represents a substantial shift in resource exploitation for Lake Ontario lake trout, average $\delta^{15} \mathrm{~N}$ values increased $<1$ trophic level $(1 \%$ o $)$ for the 2008 samples relative to those of Kiriluk et al. (1995). As lake trout are typically much larger than their prey, their shift from one prey species to another is unlikely to result in a change in predator trophic position, especially if the new prey resource does not represent a significantly different trophic level than that which it replaced in the diet (Vander Zanden et al., 2000). Round goby collected for the current study were inferred to occupy approximately the same trophic position as alewife in the Lake Ontario food web. These results suggest that the establishment of this species in Lake Ontario would be expected to negligibly affect lake trout $\delta^{15} \mathrm{~N}$ values. Human population densities and anthropogenic activities are known to affect $\delta^{15} \mathrm{~N}$ baseline values in aquatic food webs (Cabana \& Rasmussen, 1996). It is highly likely that increases in such activities in the Lake Ontario basin have contributed to the increase in lake trout $\delta^{15} \mathrm{~N}$ values observed since the initial study of Kiriluk et al. (1995). Such considerations emphasise the importance of monitoring isotopic baselines during long-term studies, especially when quantifying the impacts of invasive species on food-web trophic structure.

Our findings illustrate the growing importance of round goby to Lake Ontario lake trout and also provide information regarding the interactions and exchanges between offshore and nearshore habitats in an invaded food web. The ecological change demonstrated here for Lake Ontario lake trout contrasts with that described for this top predator from invaded inland lakes (Vander Zanden et al., 1999a,b). Specifically, owing to competition with introduced centrarchid predators, lake trout resource exploitation shifted from a reliance on nearshore to offshore resources in impacted lakes (Vander Zanden et al., 1999a,1999b). These results demonstrate the susceptibility of lake trout ecology to the impacts of invasive species and also emphasise the significance of fish species introductions to food-web ecology. McCann (2000) concluded that losses of biodiversity and species invasions have the potential to invoke major changes in food-web structure, dynamics and stability. The round goby's native range has been expanded extensively throughout Eurasia and also beyond the Laurentian Great Lakes basin in North America, increasing the potential for similar foodweb restructuring in other ecosystems (Kornis et al., 2012). Further, both intentional and unintentional fish species introductions are a global concern with generally consistent detrimental impacts observed for native species diversity and ecosystem functioning (Witte et al., 1992; Cambray, 2003; McDowall, 2006). Predicting the potential ecological ramifications that result from such food-web restructuring represents an important challenge for the management of affected freshwater ecosystems. The current study demonstrates the utility of stable isotopes for quantifying the impacts of such anthropogenic disturbances in freshwater food webs. Specifically, this ecological tracer approach combined with archived sample analysis provides the ability to quantify temporal changes in predator-prey relationships and energy flow in disturbed ecosystems. 


\section{Acknowledgments}

The authors thank J. Brush, J. Isaac, N. Jakobi, S. Wolfaardt, and M. Yuille for technical assistance in the collection, preparation and stable isotope analysis of lake trout and prey samples. This research was funded by a research grant awarded to the authors from the Great Lakes Fishery Commission with additional support received from Canada Research Chairs awarded to A.T. Fisk and G.D. Haffner. The authors also thank two anonymous reviewers for comments received on previous drafts of this manuscript. The mention of product trade names does not imply endorsement by the governments of Canada, the United States, the Province of Ontario, or New York State. This study includes data from Kiriluk et al. (1995). These data are (C) 2008 Canadian Science Publishing or its licensors and were reproduced with licensing permission granted to the authors from the National Research Council of Canada Research Press. This article is Contribution 1709 of the U.S. Geological Survey Great Lakes Science Center.

\section{References}

Borgmann U. \& Whittle D.M. (1992) Bioenergetics and PCB, DDE, and mercury dynamics in Lake Ontario lake trout (Salvelinus namaycush): a model based on surveillance data. Canadian Journal of Fisheries and Aquatic Sciences, 49, 1086-1096.

Brandt S.B. (1985) Food of trout and salmon in Lake Ontario. Journal of Great Lakes Research, 12, 200-205.

Brenden T.O., Bence J.R., Lantry B.F., Lantry J.R. \& Schaner T. (2011) Population dynamics of Lake Ontario lake trout during 1985-2007. North American Journal of Fisheries Management, 31, 962-979.

Bronte C.R., Ebener M.P., Schreiner D.R., DeVault D.S., Petzold M.M., Jensen D.A. et al. (2003) Fish community change in Lake Superior, 1970-2000. Canadian Journal of Fisheries and Aquatic Sciences, 60, 1552-1574.

Cabana G. \& Rasmussen J.B. (1996) Comparison of aquatic food webs using nitrogen isotopes. Proceedings of the National Academy of Science of the United States of America, 93, 10844-10847.

Cambray J.A. (2003) Impact on indigenous species biodiversity caused by the globalisation of alien recreational freshwater fisheries. Hydrobiologia, 500, 217-230.

Campbell L.M., Thacker R., Barton D., Muir D.C.G., Greenwood D. \& Hecky R.E. (2009) Re-engineering the Lake Erie littoral food web: the trophic function of non-indigenous PontoCaspian species. Journal of Great Lakes Research, 35, 224-231.

Connerton M.J. \& Schaner T. (2007) Acoustic Assessment of Pelagic Planktivores, 2007. New York State Department of Environmental Conservation, Lake Ontario Annual Report 2007, Albany, NY, USA.
Dietrich J.P., Morrison B.J. \& Hoyle J.A. (2006) Alternative ecological pathways in the eastern Lake Ontario food webround goby in the diet of lake trout. Journal of Great Lakes Research, 32, 395-400.

Dobiesz N.E., McLeish D.A., Eshenroder R.L., Bence J.R., Mohr L.C., Ebener M.P. et al. (2005) Ecology of the Lake Huron fish community: 1970-1999. Canadian Journal of Fisheries and Aquatic Sciences, 62, 1432-1451.

Elrod J.H., O'Gorman R., Schneider C.P., Eckert T.H., Schaner T., Bowlby J.N. et al. (1995) Lake trout rehabilitation in Lake Ontario. Journal of Great Lakes Research, 21(Suppl. 1), 83-107.

Fedorov S. (2008) GetData Graph Digitizer Software Version 2.24. Russia. Available online 26 July 2012 at: http:// getdata-graph-digitizer.com.

Fitzsimons J.D., Brown S.B., Honeyfield D.C. \& Hnath J.G. (1999) A review of early mortality syndrome (EMS) in Great Lakes salmonids: relationship with thiamine deficiency. Ambio, 28, 9-15.

Folch J., Lees M. \& Sloane Stanley G.H.S. (1957) A simple method for the isolation and purification of total lipids from animal tissues. Journal of Biological Chemistry, 226, 497-509.

France R. (1995) Differentiation between littoral and pelagic food webs in lakes using stable carbon isotopes. Limnology and Oceanography, 40, 1310-1313.

Hebert C.E., Arts M.T. \& Weseloh D.V.C. (2006) Ecological tracers can quantify food web structure and change. Environmental Science \& Technology, 40, 5618-5623.

Hebert C.E., Shutt J.L. \& Ball R.O. (2002) Plasma amino acid concentrations as an indicator of protein availability to breeding herring gulls (Larus argentatus). The Auk, 119, 185-200.

Hebert C.E., Weseloh D.V.C., Idrissi A., Arts M.T., O'Gorman R., Gorman O.T. et al. (2008) Restoring piscivorous fish populations in the Laurentian Great Lakes causes seabird dietary change. Ecology, 89, 891-897.

Hecky R.E. \& Hesslein R.H. (1995) Contributions of benthic algae to lake food webs as revealed by stable isotope analysis. Journal of the North American Benthological Society, 14, 631-653.

Hecky R.E., Smith R.E.H., Barton D.R., Guildford S.J., Taylor W.D., Charlton M.N. et al. (2004) The nearshore phosphorus shunt: a consequence of ecosystem engineering by dreissenids in the Laurentian Great Lakes. Canadian Journal of Fisheries and Aquatic Sciences, 61, 1285-1293.

Hesslein R.H., Hallard K.A. \& Ramlal P. (1993) Replacement of sulfur, carbon, and nitrogen in tissue of growing broad whitefish (Coregonus nasus) in response to a change in diet traced by $\delta^{34} \mathrm{~S}, \delta^{13} \mathrm{C}$, and $\delta^{15} \mathrm{~N}$. Canadian Journal of Fisheries and Aquatic Sciences, 50, 2071-2076.

Higgins S.N. \& Vander Zanden M.J. (2010) What a difference a species makes: a meta-analysis of dreissenid mussel impacts on freshwater ecosystems. Ecological Monographs, 80, 179-196. 
Johannsson O.E., Dermott R., Graham D.M., Dahl J.A., Millard E.S., Myles D.D. et al. (2000) Benthic and pelagic secondary production in Lake Erie after the invasion of Dreissena spp. with implications for fish production. Journal of Great Lakes Research, 26, 31-54.

Johnson T.B., Bunnell D.B. \& Knight C.T. (2005) A potential new energy pathway in central Lake Erie: the round goby connection. Journal of Great Lakes Research, 31, 238-251.

Jude D.J. \& Deboe S.F. (1996) Possible impacts of gobies and other introduced species on habitat restoration efforts. Canadian Journal of Fisheries and Aquatic Sciences, 53 (Suppl. 1), 136-141.

Kerr S.R. (1971a) Prediction of fish growth efficiency in nature. Journal of the Fisheries Research Board of Canada, 28, 809-814.

Kerr S.R. (1971b) A simulation model of lake trout growth. Journal of the Fisheries Research Board of Canada, 28, 815-819.

Kiriluk R.M., Servos M.R., Whittle D.M., Cabana G. \& Rasmussen J.B. (1995) Using ratios of stable nitrogen and carbon isotopes to characterize the biomagnifications of DDE, mirex, and PCB in a Lake Ontario pelagic food web. Canadian Journal of Fisheries and Aquatic Sciences, 52, 2660-2674.

Kiriluk R.M., Whittle D.M., Keir M.J., Carswell A.A. \& Huestis S.Y. (1997) The Great Lakes fisheries specimen bank: a Canadian perspective in environmental specimen banking. Chemosphere, 34, 1921-1932.

Kornis M.S., Mercado-Silva N. \& Vander Zanden M.J. (2012) Twenty years of invasion: a review of round goby (Neogobius melanostomus) biology, spread and ecological implications. Journal of Fish Biology, 80, 235-285.

Krueger C.C. \& Ihssen P.E. (1995) Review of genetics of lake trout in the Great Lakes: history, molecular genetics, physiology, strain comparisons, and restoration management. Journal of Great Lakes Research, 21(Suppl. 1), 348-363.

Lantry B.F. \& Lantry J.R. (2010) Lake Trout Rehabilitation in Lake Ontario, 2009. Department of the Interior, United States Geological Survey, Biological Resources Division, Great Lakes Science Center, Lake Ontario Biological Station, Oswego, NY, USA.

Martin N.V. (1954) Catch and winter food of lake trout in certain Algonquin Park lakes. Journal of the Fisheries Research Board of Canada, 11, 5-10.

Martin N.V. (1966) The significance of food habits in the biology, exploitation, and management of Algonquin Park, Ontario, lake trout. Transactions of the American Fisheries Society, 96, 415-422.

McCann K.S. (2000) The diversity-stability debate. Nature, 405, 228-233.

McDowall R.M. (2006) Crying wolf, crying foul, or crying shame: alien salmonids and a biodiversity crisis in the southern cool-temperate galaxioid fishes? Reviews in Fish Biology and Fisheries, 16, 233-422.

McGoldrick D.J., Clark M.G., Keir M.J., Backus S.M. \& Malecki M.M. (2010) Canada's national aquatic biological specimen bank. Journal of Great Lakes Research, 36, 393-398.
Miller P.J. (1986) Gobiidae. In: Fishes of the Northeast Atlantic and Mediterranean (Eds P.J.P. Whitehead, M.L. Bauchot, J.C. Hureau, J. Nielsen \& E. Tortonese), pp. 1019-1095. UNESCO, Paris.

Mills E.L., Casselman J.M., Dermott R., Fitzsimons J.D., Gal G., Holeck K.T. et al. (2003) Lake Ontario: food web dynamics in a changing ecosystem (1970-2000). Canadian Journal of Fisheries and Aquatic Sciences, 60, 471-490.

Moore J.W. \& Semmens B.X. (2008) Incorporating uncertainty and prior information in stable isotope mixing models. Ecology Letters, 11, 470-480.

Morbey Y.E., Addison P., Shuter B.J. \& Vascotto K. (2006) Within-population heterogeneity of habitat use by lake trout (Salvelinus namaycush). Journal of Fish Biology, 69, 1675-1696.

Paterson G., Whittle D.M., Drouillard K.G. \& Haffner G.D. (2009) Declining lake trout (Salvelinus namaycush) energy density: are there too many salmonid predators in the Great Lakes? Canadian Journal of Fisheries and Aquatic Sciences, 66, 919-932.

Pazzia I.M., Trudel M., Ridgway M. \& Rasmussen J.B. (2002) Influence of food web structure on the growth and bioenergetics of lake trout (Salvelinus namaycush). Canadian Journal of Fisheries and Aquatic Sciences, 59, 1593-1605.

Post D.M., Layman C.A., Arrington D.A., Takimoto G., Quattrochi J. \& Montaña C.G. (2007) Getting to the fat of the matter: models, methods and assumptions for dealing with lipids in stable isotope analyses. Oecologia , 152, 179-189.

R Development Core Team (2010) R: A Language and Environment for Statistical Computing. R Foundation for Statistical Computing, Vienna.

Rand P.S., Lantry B.F., O'Gorman R., Owens R.W. \& Stewart D.J. (1994) Energy density and size of pelagic prey fishes in Lake Ontario, 1978-1990: implications for salmonine energetics. Transactions of the American Fisheries Society, 123, 519534.

Rand P.S. \& Stewart D.J. (1998) Dynamics of salmonine diets and foraging in Lake Ontario, 1983-1993: a test of a bioenergetic model prediction. Canadian Journal of Fisheries and Aquatic Sciences, 55, 307-317.

Ray W.J. \& Corkum L.D. (2001) Habitat and site affinity of the round goby. Journal of Great Lakes Research, 27, 329-334.

Rennie M.D., Sprules W.G. \& Johnson T.B. (2009) Resource switching in fish following a major food web disruption. Oecologia, 159, 789-802.

Ryder R.A. \& Kerr S.R. (1990) Harmonic communities in aquatic ecosystems: a management perspective. In: Management of Freshwater Fisheries. Proceedings of the EIFAC Symposium, Göteborg, Sweden, May 31-June 3, 1988. (Eds L.T. Van Densen, B. Teinmetz \& R.H. Hughes), pp. 594-623. Pudoc, Wageningen, the Netherlands.

Schneider C.P., Owens R.W., Bergstedt R.A. \& O'Gorman R. (1996) Predation by sea lamprey (Petromyzon marinus) on lake trout (Salvelinus namaycush) in southern Lake Ontario 
1982-1992. Canadian Journal of Fisheries and Aquatic Sciences, 53, 1921-1932.

Scott W.B. \& Crossman E.J. (1973) Freshwater Fishes of Canada. Bulletin of the Fisheries Research Board of Canada 184, Department of the Environment, Ottawa, ON.

Taraborelli A.C., Fox M.G., Johnson T.B. \& Schaner T. (2010) Round goby (Neogobius melanostomus) population structure, biomass, prey consumption and mortality in the Bay of Quinte, Lake Ontario. Journal of Great Lakes Research, 36, 625-632.

Tillitt D.E., Zajicek J.L., Brown S.B., Brown L.R., Fitzsimons J.D., Honeyfield D.C. et al. (2005) Thiamine and thiaminase status in forage fish of salmonines of Lake Michigan. Journal of Aquatic Animal Health, 17, 13-25.

Vander Zanden M.J., Casselman J.M. \& Rasmussen J.B. (1999a) Stable isotope evidence for the food web consequences of species invasions in lakes. Nature, 401, 464-467.

Vander Zanden M.J. \& Rasmussen J.B. (1999) Primary consumer $\delta^{13} \mathrm{C}$ and $\delta^{15} \mathrm{~N}$ and the trophic position of aquatic consumers. Ecology, 80, 1395-1404.

Vander Zanden M.J. \& Rasmussen J.B. (2001) Variation in $\delta^{15} \mathrm{~N}$ and $\delta^{13} \mathrm{C}$ trophic fractionation: implications for aquatic food web studies. Limnology and Oceanography, 46, 2061-2066.

Vander Zanden M.J., Shuter B.J., Lester N. \& Rasmussen J.B. (1999b) Patterns of food chain length in lakes: a stable isotope study. The American Naturalist, 154, 406-416.

Vander Zanden M.J., Shuter B.J., Lester N. \& Rasmussen J.B. (2000) Within- and among-population variation in the trophic position of a pelagic predator, lake trout (Salvelinus namaycush). Canadian Journal of Fisheries and Aquatic Sciences, 57, 725-731.

Vander Zanden M.J. \& Vadenboncoeur Y. (2002) Fishes as integrators of benthic and pelagic food webs in lakes. Ecology, 83, 2152-2161.
Vanderploeg H.A., Nalepa T.F., Jude D.J., Mills E.L., Holeck K.T., Liebig J.R. et al. (2002) Dispersal and emerging ecological impacts of Ponto-Caspian species in the Laurentian Great Lakes. Canadian Journal of Fisheries and Aquatic Sciences, 59, 1209-1228.

Walsh M.G., Dittman D.E. \& O'Gorman R. (2007) Occurrence and food habits of the round goby in the profundal zone of southwestern Lake Ontario. Journal of Great Lakes Research, 33, 83-92.

Witte F., Goldschmidt T., Wanink J., van Oijen M., Goudswaard K., Witte-Maas E. et al. (1992) The destruction of an endemic species flock: quantitative data on the decline of haplochromine cichlid species in Lake Victoria. Environmental Biology of Fishes, 34, 1-28.

\section{Supporting Information}

Additional Supporting Information may be found in the online version of this article:

Table S1. Summary biological and stable isotope information from whole body versus dorsal muscle stable isotope comparison for lake trout samples.

Table S2. Summary of stable isotope data $\left(\delta^{13} \mathrm{C}\right)$ and two source isotope mixing model predictions for Lake Ontario lake trout collected between 1992 and 2008.

As a service to our authors and readers, this journal provides supporting information supplied by the authors. Such materials are peer-reviewed and may be re-organized for online delivery, but are not copy-edited or typeset. Technical support issues arising from supporting information (other than missing files) should be addressed to the authors.

(Manuscript accepted 11 August 2012) 
1 Table S1 Summary biological and stable isotope information from whole body vs. dorsal muscle

2 stable isotope comparison for lake trout samples. Lake trout collected October 9, 2011 from Lake

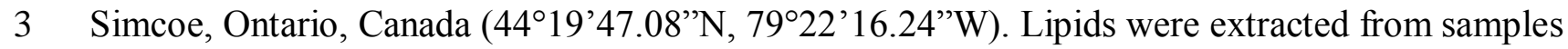

4 prior to analysis.

\begin{tabular}{|c|c|c|c|c|c|c|c|c|}
\hline $\begin{array}{l}\text { Fish } \\
\text { ID }\end{array}$ & Sex & $\begin{array}{l}\text { Fork } \\
\text { length } \\
(\mathrm{mm})\end{array}$ & $\begin{array}{c}\text { Total } \\
\text { Length } \\
(\mathrm{mm})\end{array}$ & $\begin{array}{c}\text { Mass } \\
(\mathrm{g})\end{array}$ & $\begin{array}{c}\delta^{13} \mathrm{C} \\
\text { dorsal } \\
\text { muscle } \\
(\% o)\end{array}$ & $\begin{array}{c}\delta^{13} \mathrm{C} \\
\text { whole } \\
\text { body } \\
(\%)\end{array}$ & $\begin{array}{c}\delta^{15} \mathrm{~N} \\
\text { dorsal } \\
\text { muscle } \\
(\%)\end{array}$ & $\begin{array}{c}\delta^{15} \mathrm{~N} \\
\text { whole } \\
\text { body } \\
(\%)\end{array}$ \\
\hline 1 & M & 770 & 830 & 6250 & -27.4 & -26.4 & 17.2 & 17.3 \\
\hline 2 & M & 727 & 788 & 5275 & -27.8 & -27.8 & 17.7 & 17.5 \\
\hline 3 & $\mathrm{~F}$ & 707 & 756 & 5675 & -27.5 & -26.6 & 17.2 & 17.3 \\
\hline 4 & M & 644 & 696 & 4050 & -26.5 & -28.1 & 17.3 & 17.4 \\
\hline 5 & $\mathrm{M}$ & 640 & 690 & 3575 & -26.8 & -25.7 & 17.2 & 17.3 \\
\hline 6 & $\mathrm{~F}$ & 534 & 583 & 2275 & -26.0 & -27.2 & 17.5 & 17.4 \\
\hline Means & & 670 & 724 & 4517 & -27.0 & -27.0 & 17.4 & 17.4 \\
\hline
\end{tabular}


Table S2 Summary of stable isotope data $\left(\delta^{13} \mathrm{C}\right)$ and two source isotope mixing model predictions for Lake Ontario lake trout collected between 1992 - 2008. Values indicate mean with standard deviation in parentheses.

\begin{tabular}{|c|c|c|c|c|c|c|}
\hline $\begin{array}{l}\text { Sampling } \\
\text { period }\end{array}$ & $\begin{array}{c}\text { Nearshore } \\
\delta^{13} \mathrm{C} \\
\text { baseline } \\
(\% \text { o })\end{array}$ & $\begin{array}{c}\text { Offshore } \\
\delta^{13} \mathrm{C} \\
\text { baseline } \\
(\% \text { o })\end{array}$ & $\begin{array}{c}\delta^{13} \mathrm{C} \\
\text { nearshore } \\
\text { prey } \\
(\% 0)\end{array}$ & $\begin{array}{c}\delta^{13} \mathrm{C} \\
\text { offshore } \\
\text { prey } \\
(\% \text { o) }\end{array}$ & $\begin{array}{c}\delta^{13} \mathrm{C} \\
\text { lake } \\
\text { trout } \\
(\% \mathrm{o})\end{array}$ & $\begin{array}{c}\text { Reliance on } \\
\text { nearshore } \\
\text { carbon } \\
(\%)\end{array}$ \\
\hline $1992^{\mathrm{a}}$ & -22.9 & -27.5 & -22.1 & $-26.7(0.4)$ & $-26.3(0.2)$ & $19.8(3.8)$ \\
\hline 1994-1998 & -21.5 & $-24.1(0.7)$ & -20.7 & $-24.5(0.5)$ & $-23.0(0.2)$ & $40.8(3.4)$ \\
\hline $1999-2003$ & -21.1 & -24.0 & $-20.9(0.9)$ & $-24.0(0.4)$ & $-22.2(0.2)$ & $56.4(5.0)$ \\
\hline 2008 & -21.6 & -23.9 & $-21.4(1.7)$ & $-23.2(1.0)$ & $-21.7(0.4)$ & $80.5(2.1)$ \\
\hline
\end{tabular}

${ }^{a}$ Lake trout and prey isotope data from Kiriluk et al. (1995). 